\title{
Changes in Employment Based on The Education Criterion in the EU: Skill-Upgrading or Skill-Polarization?
}

\author{
Radek Náplava
}

Mendel University in Brno, Faculty of Business and Economics, Department of Economics. Czech Republic.

\section{ARTICLE INFO}

\section{Keywords:}

Skill-upgrading

Education level

Job polarization

Labor market

JEL:

$I 21, J 21, J 24$

\begin{abstract}
This paper focuses on changes in the structure of the labor market, the main criterion being education, which determines the skill level of each worker. This allows considering highly educated workers as high-skilled workers. Due to the availability of the data set from EU KLEMS, we focus on all EU countries between 2008 and 2015. This contribution resolves the question, what the trends within jobs are in different industries of EU countries based on the education criterion. The results imply (with exceptions) skill-upgrading across all industries and in most countries (only 5 countries stagnate). Proportions of high-skilled workers increased in the countries concerned by about 3-10 p. p. Similarly, wage growth was proportional to skills. All this provides evidence about the skillupgrading process (which is consistent with the SBTC hypothesis), rather than skill-polarization. Some evidence on skill-upgrading raises the question how the growing number of high-educated workers have affected productivity. The results show that in most cases there is a direct relationship, but there are country and industry exceptions.
\end{abstract}

\section{Introduction}

The constantly changing demand structure does not allow for a reliable prediction of future changes in the employment structure. Additionally, the pace of technological progress and related changes cannot be predicted. Occupations that were twenty or thirty years ago a privilege of high-skilled workers, and which usually required a higher level of education (e.g. accountants), can now be replaced with software or even workers without a higher level of education.

Changes in the employment structure are usually attributed to the role of technological change, globalization and institutions (Goos, Manning and Salomons, 2009). In the 1980s and 1990s, it was believed that new technologies had the greatest impact on the structure of employment (Acemoglu, 1998; Autor and Katz, 1999; Berman, Bound and Machin, 1998 and others), resulting in the formulation of the skill-biased technological change (SBTC) hypothesis (Autor and Katz, 1999). This hypothesis, described in the next section, assumes a direct relationship between the demand for workers and the level of their skills; high-skilled workers are demanded more, while workers with lower skills are demanded less. The result is skill-upgrading. Against the theoretical assumptions, however, is a picture of reality that does not fully conform to these assumptions.

\footnotetext{
* Corresponding Author at: Department of Economics, Faculty of Business and Economics, Mendel university in Brno, Zemědělská 1, 613 00 Brno, Czech Republic, e-mail: xnaplava@mendelu.cz.
} 
In the last fifteen years, contributions ${ }^{1}$ have appeared that described a change in developmental tendencies in labor markets that does not correspond to the SBTC hypothesis. This change is job polarization ${ }^{2}$. The term "job polarization" comes from Goos and Manning (2007), who thus called a situation where the numbers of high-skilled workers and lowskilled workers are growing, while the number of middle-skilled workers is declining; the result of this situation is skill-polarization.

This paper focuses on a change in the structure of the labor market where the main criterion is education, which determines the skill level of each worker (Acemoglu 1998, Krueger 1993, Michaels, Natraj and Van Reenen 2014). This fact allows considering high-educated workers as high-skilled workers etc. In this paper we use the interchangeability of these terms. This also allows us to contribute to the discussion on the current labor market issue: the collision of theoretical assumptions (skill-biased technological change hypothesis) with reality (job polarization). The research question is: What are the trends of employment structure in individual sectors of EU countries based on the educational criterion? We are exploring whether there is skill-upgrading or skill-polarization. The results are presented both at sectoral level and the country level. Given the availability of the data set, the examined period is between 2008 and 2015. Changes in employment structure in terms of education are compared with changes in productivity, expressed as value added per employee, and with changes in wages.

The results of the contribution show that the evolution of the labor market structure in EU countries confirms the SBTC hypothesis. The increased proportion of high-skilled workers, found by this contribution as regards highly educated workers, is a trend across almost all industries, while their reduced proportion is rather exceptional. This supports the SBTC hypothesis, which assumes an increasing number of high-skilled workers. Similarly, wage growth was proportional to skills. Some evidence about the skill-upgrading process raises the question: How did the changing structure affect productivity? The results show that the growing number of educated workers (mostly high-educated) has affected productivity positively. The expected direct relationship is common in most cases (in most countries and most industries), but there are country and industry exceptions.

The rest of the contribution is structured as follows. Section 2 describes the current structural changes that are taking place on the labor market, in particular SBTC hypothesis and polarization on the labor market. Section 3 looks at the specification of data sources and measurement issue. Section 4 shows how the structure of employment has changed, when regarding the level of education as the main criterion. The question how it affected the productivity and wages is also addressed. Conclusion is presented in section 5.

\section{Literature Review}

Card and DiNardo (2002, p. 734) described SBTC as follows: "burst of new technology caused a rise in the demand for highly skilled workers". High-skilled workers generally need more new technologies to work, implying not only a complementary relationship between human capital and new technologies but also a direct proportion: involving more and more new technologies requires more high-skilled workers to work with them (or who would only operate the new technology). A reverse relationship also applies: new technology usually requires more skilled workers (Card and DiNardo, 2002).

The impact of technology on the demand is obvious: absolute figures have increased, and despite the relatively large increase in real wages, this has not been reflected in the

\footnotetext{
${ }^{1}$ Autor, Levy and Murnane (2003), Autor, Katz and Kearney (2006), Goos, Manning and Salomons (2009, 2014), Acemoglu and Autor (2011), and others.

2 Sometimes we can see the term "missing middle" (Oldenski, 2014), which basically reflects the negative effect of job polarization.
} 
unemployment rate. The conjecture that technology "destroys" (or "steals") jobs is in the eyes of society more, because "winners" of introducing new technologies are not seen as much as those "defeated" (Manning, 2004). Literature dealing with SBTC sometimes shows the problems of higher inequality (see Acemoglu, 2002), but this is contradicted by Card and DiNardo (2002), according to whom the SBTC cannot explain any other dimensions of wage inequalities such as age or race. Manning (2004) pointed to the neglected fact: "average job" is improving. Weiss (2008), on the other hand, said SBTC does not necessarily deepen wage inequality. The reason is that wages do not depend on natural productivity only but also on money productivity. Consumer preferences (omitted in this area of research) stand behind the growth in demand, which is reflected in wages (even without growth in natural productivity). Contributions about the issue of job polarization have to deal with methodological problems that arise from the identification of this phenomenon. The first problem is finding a suitable sorting criterion which will allow dividing employees into high-, middle- and low-skilled. Most often, the division is determined by individual occupations, which are classified according to the type of work performed and the skill level (Autor, Levy and Murnane, 2003; Goos, Manning and Salomons, 2014, and others). ${ }^{3}$ Another way can be a division based on wages, where the level of wages is directly proportional to the skills (Bárány and Siegel 2018a). Bárány and Siegel (2018b) classified the industry into high-skilled services, goods (mainly manufacturing, agriculture, and construction), and low-skilled services. Classification of industries is given by typical occupations within them, which are categorized by tasks (similar to Autor, Levy and Murnane, 2003; see below). Finally, another possible way of dividing the industry into high-, middle- and low-skilled is by the value added generated by each industry (Amoroso and Moncada-Paterno-Castello, 2018). This includes the assumption of a homogeneous employee structure within each sector.

Another problem is the (un)availability of the data sources needed to identify the polarization. The most data (and at the same time the best available) are provided by the US labor market. This is one of the reasons why attention turned there first, and why the US labor market is the best documented. Job polarization in US has been proven since the 1980s (Autor and Dorn, 2013; Autor, Katz and Kearney, 2006), or even the 1950s (Bárány and Siegel, 2018a). Later, the presence of polarization was also confirmed for the UK (Goos and Manning, 2007) and some European countries (Goos, Manning and Salomons, 2009; Pertold-Gebicka, 2014).

What can explain job polarization? Autor, Levy and Murnane (2003) came up with an explanation, which was called "ALM hypothesis". Later it was renamed by Goos, Manning and Salomons (2014) as routine-biased technological change ("RBTC"). This title is selfexplanatory. SBTC explains the changes based on skills, RBTC based on tasks. Autor, Levy and Murnane (2003) divided occupations by tasks into the routine, non-routine, manual, and cognitive ones. Workers who perform routine tasks can be replaced by a new technology: a machine or an algorithm (technology is a substitute for them); while workers who perform non-routine tasks will face an increasing demand as they are complementary to new technologies. ${ }^{4}$ Thus, in general: computerization does not replace skills but tasks. Moreover, if a routine profession is well defined, then it is also possible to replace a middle-skilled worker with a less qualified worker (which is usually the case of offshoring). The RBTC is an explanation widely accepted among economists (Autor, Levy and Murnane, 2003, Manning, 2004, Goos and Manning, 2007). It is certainly not a rejection of the SBTC theory as such, skill-upgrading across sectors and professions has been demonstrated by many studies

\footnotetext{
${ }^{3}$ For example, classification of occupations ISCO-08. Authors' own classifications are not exceptional, see Dorn (2009) or Autor and Dorn (2013), who slightly modified the ISCO-08 classification.

${ }^{4}$ The routineness of an occupation is measured, for example, by the Routine Task Intensity (RTI) index, which is based on the Autor, Levy and Murnane (2003). It was also developed and edited by Autor and Dorn (2013) and Autor, Dorn and Hanson (2015).
} 
(Fernandez-Macias, 2012). The RBTC only complements the SBTC by explaining the polarization. Additionally, it is important to remember that not all the tasks (middle- or lowskilled) can be replaced by new technologies. There are still constraints resulting from imperfect technologies in specific areas or from economic constraints: it is not always worthwhile to introduce new sophisticated technologies.

Offshoring is another explanatory factor of job polarization (Goos, Manning and Salomons, 2009, 2014; Crinò, 2009; Oldenski 2014). In general, job polarization is due to technological change (computerization) and globalization (offshoring). We can add one more reason, which is not documented as much as the impact of ICT and offshoring, but is relevant. Mazzolari and Ragusa (2014) documented that the rise in demand for low-skilled workers is partly due to the higher consumption of high-skilled workers whose wages grow faster (see Acemoglu and Autor, 2011), and can therefore demand a larger amount of low-skilled (personal) services. In other words, growing wealth of high-skilled workers pulls up low-skilled workers.

Polarization is not a domain of only a few industries, where the greatest proportion of routine jobs could be expected. Autor, Dorn and Hanson (2015) showed that job polarization is reflected both within manufacturing and non-manufacturing sectors. This implies a structural change across the whole labor market (Goos, Manning and Salomons, 2009; Bárány and Siegel 2018a). That is why we are focusing on the whole economy divided into individual industries. Finally, given that wages are affected by the demand for workers, it is not surprising that polarization is also reflected in wages. Goos and Manning (2007) showed that when occupations are divided by wage distribution, we can find routine jobs in the middle, while non-routine occupations are at the edges of wage distribution.

\section{Data and Methodology}

Given the research question, it is necessary to define the relationship between skill levels and the highest level of education attained. Manning (2004) considered those who are more educated to be skilled workers. Similarly, Crinò (2009) and Krueger (1993) considered those more educated to be high-skilled workers. Mutual interchangeability of skill levels and level of education is common in literature, see Michaels, Natraj and Van Reenen (2014). Thus, for the division of skills, the highest level of education attained is used..$^{5}$ Table 1 contains information about the highest level of education achieved and the level of skills. In literature, we most often encounter a division of skills into three categories; therefore, three categories are used also in this study. ${ }^{6}$

Table 1.

Distribution of skill levels according to the level of education attained

\begin{tabular}{llll}
\hline Educational attainment & & level of education & level of skills \\
\hline $\begin{array}{l}\text { primary education } \\
\text { secondary education }\end{array}$ & $\begin{array}{l}\text { no formal } \\
\text { qualifications }\end{array}$ & low-educated & low-skilled \\
$\begin{array}{l}\text { upper secondary } \\
\text { post-secondary non-tertiary education }\end{array}$ & intermediate & middle-educated & middle-skilled \\
first stage of tertiary education & university & high-educated & high-skilled \\
second stage of tertiary education & graduates & & \\
\hline
\end{tabular}

Source: EU KLEMS and ISCED (1997)

If workers are rewarded on the basis of their productivity, changes in relative productivity must be reflected in changes in their relative wages (Acemoglu, 2002). Therefore, the relative

\footnotetext{
${ }^{5}$ Arguments regarding the relationship between skill levels and education can be found in Mason, Williams and Cranmer (2009).

${ }^{6}$ An exception is, for example, Weiss (2008) sorting into the skilled/unskilled categories.
} 
changes in the volume of wages for high-, middle- and low-skilled workers across sectors are also reported in the results.

The research question will be answered based on the observation of changes in the proportion of employees and their highest level of education attained. Another measure will be the relative changes in the volume of wages divided by the highest level of education attained. This contribution contains descriptive methods ${ }^{7}$ and a correlation analysis is used to measure the dependence between the relative change in the number of high-, middle- and low-skilled workers and the change in their relative wages.

The main data source is the EU KLEMS project database. ${ }^{8}$ The EU KLEMS project includes a database containing information on productivity, technological change, economic growth, capital formation and others. All data are at NACE (Rev. 2) level of industries. The individual indicators differ in the length of their time series; the longest ranges up to 1970. The period available for the changes in education and wages used there covers the years 2008-2015. ${ }^{9}$ Over the years, twenty-eight EU countries have been investigated. The database provides data for each year and country by gender, age (15-29, 30-49, 50 years, and over) and the highest education attained for eighteen industries according to NACE classification (sector A-R). This article uses abbreviations for each industry, the full names are referenced here:

$\mathrm{A}=$ Agriculture, Forestry and Fishing; $\mathrm{B}=$ Mining and quarrying; $\mathrm{C}=$ Manufacturing; $\mathrm{D}=$ Electricity \& gas; $\mathrm{E}=$ Water and sewerage; $\mathrm{F}=$ Construction; $\mathrm{G}=$ Wholesale and retail trade; $\mathrm{H}=$ Transport and Storage; $\mathrm{I}=$ Hotels \& catering; $\mathrm{J}=$ Information and Communication; $\mathrm{K}=$ Financial intermediation; $\mathrm{L}=$ Real Estate; $\mathrm{M}=$ Professional, Scientific and Technical activities; $\mathrm{N}=$ Administrative and Support Service activities; $\mathrm{O}=$ Public administration and defence; compulsory social security; $\mathrm{P}=$ Education; $\mathrm{Q}=$ Health and social work; $\mathrm{R}=$ Arts, Entertainment and Recreation

The results chapter includes two terms that need to be explained: trend improvement and trend worsening. The structure of each industry is composed of a high-, middle- and loweducated workers share. For example, in the Czech Republic in 2008, middle-educated workers made up the largest share in the ICT sector. Starting in 2012 (until the end of the reporting period of 2015) a change occurred - the largest proportion was made up of higheducated workers. This change in trend is "trend improvement"; the level of education in the industry improved. "Trend worsening" is the opposite.

\section{Results}

\subsection{Changes in the structure of employment based on education at sectoral level in all EU countries}

First, attention is paid to changes in the structure of education level across industries. The results are shown in Table 2 below. Trend improvement/worsening means that there is an improvement/worsening in the trend which will take effect at least in two consecutive periods (see paragraph above). For example: France had the largest share of middle-skilled workers in the "D" industry during 2008-2012, but during the years 2013-2015 there was a change in the proportion towards high-skilled workers; that was an improvement in the trend. The same applies to other countries.

\footnotetext{
7 This approach is not exceptional in thematic literature. See for example Fernandez-Macias (2012), who, without use of an empirical apparatus, endeavors with difficulty to identify job polarization.

${ }^{8}$ See www.euklems.net. For a summary overview of the methodology and construction of the EU KLEMS database, see Jäger (2017).

${ }^{9}$ Making relevant conclusions from a relatively short time series is not necessarily a problem. For example Oldenski (2014) worked with a seven-year time series only.
} 
Table 2.

Changes in the structure of the education level in industries between 2008 and 2015.

\begin{tabular}{|c|c|c|c|c|c|}
\hline Country & $\begin{array}{c}\text { Trend } \\
\text { improvement }\end{array}$ & $\begin{array}{c}\text { Trend } \\
\text { worsening }\end{array}$ & Country & $\begin{array}{c}\text { Trend } \\
\text { improvement }\end{array}$ & $\begin{array}{c}\text { Trend } \\
\text { worsening }\end{array}$ \\
\hline Austria & $\mathrm{J}$ & - & Italy & $\mathrm{I}, \mathrm{N}$ & - \\
\hline Belgium & - & - & Latvia & - & - \\
\hline Bulgaria & $\mathrm{L}, \mathrm{O}$ & - & Lithuania & $\mathrm{D}, \mathrm{L}$ & - \\
\hline Croatia & $\mathrm{A}, \mathrm{J}$ & - & Luxembourg & $\mathrm{B}, \mathrm{J}$ & - \\
\hline $\begin{array}{l}\text { Cyprus } \\
\text { Czech }\end{array}$ & $\mathrm{R}$ & D & Malta & $\mathrm{D}, \mathrm{J}, \mathrm{O}, \mathrm{Q}, \mathrm{R}$ & - \\
\hline Republic & $\mathrm{J}, \mathrm{M}$ & - & Netherlands & $\mathrm{B}, \mathrm{D}, \mathrm{E}$ & - \\
\hline Denmark & A, B, I & D & Poland & $\mathrm{R}$ & - \\
\hline Estonia & $\mathrm{L}, \mathrm{R}$ & - & Portugal & $\mathrm{Q}, \mathrm{R}$ & - \\
\hline Finland & Q & - & Romania & $\mathrm{O}$ & - \\
\hline France & D & - & Slovakia & K & - \\
\hline Germany & $\mathrm{J}$ & - & Slovenia & $\mathrm{J}, \mathrm{K}$ & - \\
\hline Greece & - & - & Spain & - & - \\
\hline Hungary & $\mathrm{K}$ & $\mathrm{R}$ & $\begin{array}{l}\text { Sweden } \\
\text { United }\end{array}$ & Q & - \\
\hline Ireland & $\mathrm{A}, \mathrm{B}, \mathrm{C}$ & - & Kingdom & - & - \\
\hline
\end{tabular}

Source: author's calculation based on EU KLEMS data.

Note: A-R are industry abbreviations; their full names are given in the methodology. "-" means that the education structure of the industry did not change.

The results of the changes in the structure of the labor market at the level of education correspond to the SBTC hypothesis - they imply that there is primarily a rise in high-skilled workers at the expense of middle-skilled and low-skilled workers. Improvements in most industries (five in total) can be seen in Malta. A relatively large improvement was found for Denmark, Ireland, and the Netherlands (in three industries). On the contrary, there was no improvement in Belgium, Greece, Spain, and the UK. Except for these countries, there was typically an improvement in one (ten countries) or two sectors (nine countries). Trend worsening only occurred in Cyprus, Denmark, and Hungary. Altogether, there were forty-two positive trends in the period under review, while a negative trend was seen only three times. Table 3 summarizes the trend improvement/worsening at the industrial level. The trend in the "J" industry (ICT) most frequently improved (in seven countries), reflecting the development of this sector in the examined period. There was no improvement in the "F", "G", "H", and "P" industries. It is not difficult to explain the absence of trend improvement in the "P" (Education) industry. This industry had the largest proportion of high-skilled employees at the beginning of the examined period; therefore, no improvement was expected. A trend worsening occurred in two sectors only: Electricity \& Gas; and Arts, Entertainment and Recreation. Industries that are stagnant or have a tendency to worsen (in the case of Electricity \& Gas) are considered to be, according to Amoroso and Moncada-PaternoCastello (2018), middle-skilled industries. Their criterion is proportion of high-, middle-, and low-skilled workers according to the ISCO classification in each industry. ${ }^{10}$

\footnotetext{
${ }^{10}$ Evaluation of each industry is based on the assumption of a homogeneous structure of occupations within each sector. If similar simplifications were to be used in this paper, we could say that the "P" industry (Education) is a high-skill industry because it contains the highest proportion of highly educated and hence high-skilled workers.
} 
Table 3.

Count of trend improvement/worsening at the industrial level during 2008-2015.

\begin{tabular}{lllllllllllllllllll}
\hline Industry & $\mathbf{A}$ & $\mathbf{B}$ & $\mathbf{C}$ & $\mathbf{D}$ & $\mathbf{E}$ & $\mathbf{F}$ & $\mathbf{G}$ & $\mathbf{H}$ & $\mathbf{I}$ & $\mathbf{J}$ & $\mathbf{K}$ & $\mathbf{L}$ & $\mathbf{M}$ & $\mathbf{N}$ & $\mathbf{O}$ & $\mathbf{P}$ & $\mathbf{Q}$ & $\mathbf{R}$ \\
\hline + trend & 3 & 4 & 1 & 4 & 1 & 0 & 0 & 0 & 2 & 7 & 3 & 3 & 1 & 1 & 3 & 0 & 4 & 5 \\
- trend & 0 & 0 & 0 & 2 & 0 & 0 & 0 & 0 & 0 & 0 & 0 & 0 & 0 & 0 & 0 & 0 & 0 & 1 \\
\hline
\end{tabular}

Source: author's calculation based on EU KLEMS data.

Note: "+ trend"/ "- trend" means trend improvement/worsening, respectively, for at least two years.

A-R are industry abbreviations; their full names are given in the methodology.

The results presented in Table 4 below can be divided into three parts. The first part includes a relative change in the proportion of high-, middle- and low-skilled workers. This is the sum of all 18 NACE sectors for each EU country. In the second part, there is a relative change in the volume of wages of high-, middle- and low-skilled workers. Again, this is the sum of all industries. Finally, in the third part of the table, a correlation coefficient is used to measure the strength of dependence between the first and the second parts of the table: between the relative change in the proportion of skilled workers and the relative change in their wages.

Table 4.

Relative changes in the proportion of high-, middle-and low-skilled workers between 2008 and 2015.

\begin{tabular}{|c|c|c|c|c|c|c|c|}
\hline \multirow{2}{*}{ Country } & \multicolumn{3}{|c|}{ Education (skill) level } & \multicolumn{3}{|c|}{ wages } & \multirow{2}{*}{ Corr. } \\
\hline & High & Middle & Low & High & Middle & Low & \\
\hline Bulgaria & 0.06 & -0.03 & -0.03 & 0.04 & -0.02 & -0.03 & $0.9912 *$ \\
\hline Czech Republic & 0.08 & -0.06 & -0.02 & 0.02 & 0.00 & -0.02 & 0.6934 \\
\hline Denmark & 0.03 & 0.02 & -0.06 & 0.03 & 0.05 & -0.07 & 0.9670 \\
\hline Germany & 0.03 & -0.01 & -0.02 & -0.05 & 0.08 & -0.03 & -0.4590 \\
\hline Estonia & 0.05 & -0.04 & -0.01 & -0.01 & 0.02 & -0.01 & -0.7559 \\
\hline Ireland & 0.08 & -0.01 & -0.08 & 0.10 & 0.01 & -0.11 & $0.9881 *$ \\
\hline Greece & 0.07 & -0.05 & -0.03 & 0.07 & 0.00 & -0.07 & 0.7777 \\
\hline Spain & 0.07 & -0.01 & -0.06 & 0.07 & 0.01 & -0.08 & 0.9695 \\
\hline France & 0.09 & -0.02 & -0.07 & 0.08 & -0.02 & -0.06 & $0.9996 *$ \\
\hline Croatia & 0.06 & -0.04 & -0.02 & 0.07 & -0.05 & -0.02 & $0.9986^{*}$ \\
\hline Italy & 0.04 & 0.00 & -0.04 & -0.02 & 0.08 & -0.06 & 0.2774 \\
\hline Cyprus & 0.04 & 0.00 & -0.04 & 0.03 & 0.01 & -0.04 & 0.9707 \\
\hline Latvia & 0.05 & -0.03 & -0.02 & 0.05 & -0.03 & -0.02 & $1.0000 * * *$ \\
\hline Lithuania & 0.07 & -0.07 & -0.01 & 0.10 & -0.09 & -0.01 & $1.0000 * * *$ \\
\hline Luxembourg & 0.09 & -0.06 & -0.03 & 0.09 & -0.02 & -0.07 & 0.8773 \\
\hline Hungary & 0.04 & -0.04 & -0.01 & 0.04 & -0.02 & -0.02 & 0.9286 \\
\hline Malta & 0.05 & 0.00 & -0.06 & 0.06 & 0.01 & -0.07 & $0.9968 *$ \\
\hline Netherlands & 0.06 & -0.01 & -0.05 & 0.00 & 0.02 & -0.02 & 0.3592 \\
\hline Austria & 0.15 & -0.12 & -0.03 & 0.06 & -0.03 & -0.03 & 0.9449 \\
\hline Poland & 0.10 & -0.08 & -0.02 & 0.06 & -0.03 & -0.03 & 0.9449 \\
\hline Portugal & 0.08 & 0.08 & -0.16 & 0.06 & 0.11 & -0.17 & 0.9859 \\
\hline Romania & 0.08 & -0.08 & 0.00 & 0.05 & -0.05 & 0.00 & $1.0000 * * *$ \\
\hline Slovenia & 0.07 & -0.04 & -0.02 & -0.01 & 0.05 & -0.03 & -0.4372 \\
\hline Slovakia & 0.06 & -0.06 & 0.00 & -0.01 & 0.01 & -0.01 & -0.8660 \\
\hline Finland & 0.05 & 0.01 & -0.06 & 0.07 & -0.01 & -0.06 & 0.9586 \\
\hline Sweden & 0.07 & -0.06 & -0.01 & 0.09 & -0.06 & -0.03 & 0.9799 \\
\hline United Kingdom & 0.07 & -0.05 & -0.05 & 0.07 & -0.03 & -0.04 & $0.9966^{*}$ \\
\hline
\end{tabular}

Source: author's calculation based on EU KLEMS data. 
Note: Level of skills is determined according to Table 1 above. Corr. $=$ correlation coefficient. $* / * * / * * *$ indicate significance at the 10,5 and 1 percent levels, respectively.

In the Czech Republic (second line of Table 4), the share of high-skilled workers increased by 8 percentage points between 2008 and 2015. This increase occurred at the expense of middle-skilled workers (-6 p.p.) and low-skilled workers (-2 p.p.). The share of wages of high-skilled workers in all wages increased by 2 p.p., while the share of wages by middleskilled workers did not change and the share of low-skilled decreased by 2 p.p. The correlation coefficient, which indicates the dependence between the change in the number of workers according to their attained level of education and the change in their wages, indicates a value of almost 0.7 , but is not statistically significant.

We can see that the growing proportion of high-skilled workers was a trend in all countries. Typically, figures increased between 3-10\% between 2008 and 2015. Austria is significantly out of this range (15\%). For middle- and low-skilled workers, the trend is a reduction in proportion. It should be noted that this loss can be caused by: death, migration, and retirement. The trend is more severely violated only in the cases of Portugal, Denmark, and Finland. An increasing trend in wage volumes for high-skilled workers is in line with the rising demand for them (SBTC hypothesis). However, there are countries where the drop in the volume of low-skilled workers is lower than or equal to that of middle-skilled workers. This, due to the theoretical assumptions about the relationship between labor demand and wages, implies that the demand for middle-skilled workers drops faster than the demand for low-skilled workers (this could point to job polarization). This is happening in eight countries: Croatia, Latvia, Lithuania, Hungary, Austria, Poland, Romania, and Sweden. Evolution in the remaining twenty countries corresponds to the requirements of skillupgrading and its linkage to wages. The correlation coefficient is significant only in one third countries - that is, the relationship between the change in proportion of high-, middle- and low-skilled workers and the volume of their wages in all wages is statistically significant only in nine EU countries.

\subsection{Changes in productivity and wages caused by the change in the number of high- educated workers}

The previous results have clearly demonstrated an increase in high-educated workers across all EU countries. Naturally, the greater proportion of more skilled (educated) workers - skillupgrading - raises the question of how much this has translated into productivity growth. In this section, we will narrow the research area to the Czech Republic and the surrounding countries (Germany, Austria, Slovakia, and Poland). To these five countries, we will add three of the richest (Denmark, Sweden, Ireland) and the three poorest EU countries (Bulgaria, Romania, and Latvia). ${ }^{11}$ Again, we will use the NACE classification of the industries, but now not every sector will be separate. We will use Eurostat's approach where some industries with similar characteristics are combined. Four sectors of B-E are linked together, but the Cindustry appears also separately, as it plays a dominant role in many countries (such as the Czech Republic). In addition, there are three G-I industries (all classified as less knowledge intensive services), two M-N industries and three $\mathrm{O}-\mathrm{Q}$ industries (knowledge intensive services). Productivity is expressed as value added per employee and its relative changes are observed (Bárány and Siegel, 2018b; Ngai and Petrongolo, 2017). This indicator is also provided within the EU KLEMS database; its construction and comparison with other indicators is discussed in O'Mahony and Timmer (2009). First, Table 5 below provides the change in the number of high-educated employees in percentage points. Then, changes in

\footnotetext{
${ }^{11}$ The richest and poorest countries are determined by average GDP per capita over the years 2008-2015.
} 
productivity are shown in Table 6. Finally, Table 7 contains changes in wages of higheducated workers. It is observed how the wages of high-educated workers have changed compared to all wages in the economy (the sum of low-educated, middle-educated and higheducated workers).

Table 5.

Change in the number of high-educated employees; in percentage points between 2008-2015

\begin{tabular}{lllllllllllll}
\hline NACE industry & A & B-E & C & F & G-I & J & K & L & M-N & O-Q & R \\
\hline Neighboring & A & 7.8 & 11.78 & 15.39 & 6.63 & 12.03 & 27.65 & 25.66 & 27.35 & 17.89 & 11.57 & 16.41 \\
countries & CZ & 2.44 & 6.38 & 4.12 & 7.71 & 2.82 & 19.99 & 10.44 & 9.11 & 5.94 & 14.42 & 10.84 \\
& D & 2.98 & 3.73 & 4.41 & -0.12 & 1.59 & 8.86 & 4.45 & 5.36 & 3.59 & -0.13 & 2.95 \\
& PL & 2.9 & 9.21 & 6.64 & 3.59 & 8.21 & 15.44 & 14.39 & 13.43 & 8.81 & 11.66 & 11.78 \\
& SK & 1.53 & 6.81 & 4.08 & 8.53 & 6.11 & 10.3 & 11.12 & 1.85 & 4.2 & 5.42 & 5.78 \\
\hline EU average & & 2.82 & 6.49 & 5.93 & 5.13 & 5.12 & 11.78 & 12.17 & 6.23 & 6.22 & 7.15 & 8.3 \\
\hline Rich & DK & -10.54 & 6.93 & 6.15 & -0.51 & 3.91 & 5.66 & 13.04 & -0.11 & 5.13 & 6.1 & 2.5 \\
countries & SWE & 5.82 & 10.55 & 7.67 & 2.15 & 5.19 & 9.82 & 10.33 & 5.82 & 7.01 & 6.88 & 4.38 \\
& IRL & 2.57 & 11.04 & 9.64 & 3.83 & 7.82 & 11.29 & 18.54 & 4.64 & 5.85 & 7.25 & 10.53 \\
\hline Poor & BG & 2.05 & 4.85 & 4.448 & 3.3 & 3.8 & 11.75 & 14.18 & 22.41 & 1.87 & 5.62 & 8.01 \\
countries & RO & 0.68 & 5.61 & 2.2 & 0.57 & 4.58 & 9.17 & 14.37 & 18.84 & 6.92 & 11.6 & 16.87 \\
& LV & 3.06 & 1.46 & 1.76 & 8.81 & 4.8 & 9.17 & 15.61 & -7.76 & 2.09 & 12.82 & 6.3 \\
\hline
\end{tabular}

Source: author's calculation based on EU KLEMS data

Note: $\mathrm{A}=$ Austria; $\mathrm{BG}=$ Bulgaria; $\mathrm{CZ}=$ Czech Republic; $\mathrm{D}=$ Germany; $\mathrm{DK}=$ Denmark; IRL = Ireland; LV = Latvia; $\mathrm{PL}=$ Poland; $\mathrm{RO}=$ Romania; $\mathrm{SK}=$ Slovakia; $\mathrm{SWE}=$ Sweden.

A-R are industry abbreviations; their full names are given in the methodology.

Table 5 shows that the rise in high-educated workers is at the level of all industries in all countries. For example, in Austria, which is in the first line, the number of high-educated workers rose in all industries. In industry A, their share grew by 7.8 p. p., in industry $\mathrm{J}$ by 27.65 p. p., etc. There are only six minor exemptions that affect three countries - Germany (industry F and O-Q), Denmark (A, F, L), and Latvia (L). There was a decrease in the number of high-educated workers in these industries. A negative sign means that either (a) the level of education may have increased, or (b) the employee was moved to another industry, or (c) to another country. As these are high-educated workers, increasing the level of education is out of the question, so moving to another industry or another country is a possible explanation. Transfers to other countries should be of a marginal nature, so transfers between sectors are the most likely explanation.

As far as the Czech Republic and neighboring countries are concerned, the biggest changes in the number of high-educated workers occurred in Austria - very significant changes amounting to 25-27 p. p. were carried out in sectors that are knowledge demanding: J, K, L. The Czech Republic as well as Poland also achieved relatively large growth values, albeit not as in Austria. The growth of high-educated workers in Slovakia was a bit lower, but it was still higher than in the case of Germany, which in terms of growth values ranked the last within the neighboring countries. The common denominator of these countries was the largest increase in high-educated workers, typically in the $\mathrm{J}, \mathrm{K}$ and $\mathrm{O}-\mathrm{Q}$ sectors (all considered knowledge intensive services). This reflects the EU-wide result, where higheducated workers grew the most in the same industries, i.e. industries that are non-industrial in nature and rank among knowledge intensive services.

If we choose to compare only a part of rich and poor countries, we can conclude that the increase in high-educated workers in the more capital-intensive industries (sector A-I) is higher in rich countries than in poor countries. Conversely, in the $\mathrm{J}, \mathrm{K}$ and $\mathrm{L}$ industries (a relatively knowledge-intensive sector), the increase is slightly larger in poor countries. The 
explanation is probably that in poorer countries these industries are not developed as in the richer countries, so their growth potential is higher (catch-up effect).

Table 6 below shows the percentage change in productivity in each industry. Change in productivity is represented by a change in value added per employee.

Table 6.

Change in the productivity; in percentage points between 2008-2015

\begin{tabular}{lllllllllllll}
\hline NACE industry & A & B-E & C & F & G-I & J & K & L & M-N & O-Q & R \\
\hline Neigh- & A & -15.76 & -0.25 & 15.04 & 3.26 & 11.42 & 3.79 & 4.79 & 25.05 & 5.66 & 11.79 & 1.97 \\
boring & CZ & 55.44 & 4.07 & 27.24 & 10.21 & 3.63 & 3.61 & 12.23 & 10.81 & -1.21 & 18.86 & -7.64 \\
countries & D & -26.65 & 1.04 & 18.47 & 28.53 & 6.48 & 19.14 & 19.72 & 9.41 & 1.22 & 20.57 & 15.97 \\
& PL & 33.83 & 42.44 & 56.76 & 45.52 & 39.84 & 10.88 & 16.32 & 16.77 & 27.31 & 29.46 & 7.78 \\
& SK & 16.42 & 12.12 & 25.05 & 12.37 & 9.34 & -5.95 & 58.21 & -5.45 & -1.92 & 19.13 & 117.23 \\
\hline EU average & & 2 & 3.32 & 20.8 & 17.91 & 9.04 & 4.54 & 19.59 & 14.69 & 2.5 & 12.11 & 10.33 \\
\hline Rich & DK & 36.42 & 2.49 & 56.8 & 4.06 & 14.33 & 17.26 & 30.14 & 19.63 & 21.59 & 13.77 & 7.78 \\
countries & SWE & -11.33 & -3.41 & 29.58 & 0.61 & 11.85 & 31.88 & 62.55 & 5.95 & 18.45 & 19.06 & 22.52 \\
& IRL & 39.22 & 143 & 232.4 & -1.67 & 5.42 & 56.26 & 11.89 & -17.55 & 45.28 & -3.52 & 8.76 \\
\hline Poor & BG & -21.07 & 81.05 & 69.9 & 9.14 & 33.27 & -17.17 & 12.91 & 0.27 & 59.27 & 57.73 & 8.76 \\
countries & RO & -2.67 & 94.92 & 69.76 & -11.2 & 13.53 & -9.15 & 107.71 & 235.52 & 93.23 & 24.21 & 311.69 \\
& LV & -2.25 & 33.9 & 46.14 & 0.66 & 23.14 & 0.3 & 19.97 & 32.45 & -6.15 & 11.27 & 26.46 \\
\hline
\end{tabular}

Source: author's calculation based on EU KLEMS data

Note: $\mathrm{A}=$ Austria; $\mathrm{BG}=$ Bulgaria; $\mathrm{CZ}=$ Czech Republic; $\mathrm{D}=$ Germany; $\mathrm{DK}=$ Denmark; IRL = Ireland; LV = Latvia; $\mathrm{PL}=$ Poland; $\mathrm{RO}=$ Romania; $\mathrm{SK}=$ Slovakia; $\mathrm{SWE}=$ Sweden.

A-R are industry abbreviations; their full names are given in the methodology.

The evaluation of the results from Table 6 assumes that they are compared with Table 5. As a prerequisite, we could refer to a situation where the number of high-educated workers is increasing in the industry and this will translate into higher productivity (higher value added per employee). For example, in Austria, which is in the first line, productivity in industry A decreased by 15.76 p. p. and in B-E by 0.25 p. p. In other industries, the expected productivity growth has already occurred (expected due to the increase in the number of higheducated workers in all industries). Looking at both tables, we can see that this assumption is violated in some countries and industries. In general, productivity tended to grow more in the poorer part of the EU than in the richer one. In fact, only Ireland within the rich EU countries had relatively high growth rates (due to the manufacturing industry). The fastest growth of productivity within the EU can be found in manufacturing $(\mathrm{C})$, financial intermediation $(\mathrm{K})$, and construction $(\mathrm{F})$. The first two are the only sectors where, without exception, the growth of high-educated workers is accompanied by growth in value added per employee.

The assumption of a direct relationship between the change of high-educated workers and the change in productivity applies only to Poland. For the other countries, there is always at least some exception. Anomalies can be especially found in industries A, J, and M-N.

In industry $\mathrm{A}$, we can find a situation in six countries where the increase in the number of high-educated workers translated into a decline in productivity. And once, on the other hand, we can find a situation where the decline of high-educated workers led to growth in productivity. In industry $\mathrm{J}$ (ICT), a relatively large increase in high-educated workers resulted in growth in productivity, but not everywhere (it dropped in Slovakia, Bulgaria, and Romania) and not so much across the EU as in other industries: industry F (construction) grew four times more and industry $\mathrm{C}$ (manufacturing) even five times more. While the M-N industry manifested a relatively large increase in high-educated workers, productivity gains were not so great compared to other industries. Even in the Czech Republic and Slovakia, productivity fell despite the rise in high-educated workers. M-N industry grew as the second slowest throughout the EU, albeit that includes M (professional, scientific and technical 
activities). Looking at individual groups of countries, productivity grew faster in the poorer part of the EU (except for Latvia, despite a rise in high-educated workers).

Table 7.

Change in the volume of wages for high-educated workers (of the volume of all wages); in percentage points between 2008-2015

\begin{tabular}{lllllllllllll}
\hline NACE industry & & A & B-E & C & F & G-I & J & K & L & M-N & O-Q & R \\
\hline \multirow{4}{*}{$\begin{array}{l}\text { Neighboring } \\
\text { countries }\end{array}$} & A & 7.08 & 22.11 & 11.32 & 5.54 & 15.28 & 11.45 & 11.55 & 12.78 & 10.48 & 8.45 & -2.05 \\
& CZ & 0.66 & 27.69 & 3.86 & 1.84 & -1.50 & 9.94 & -3.25 & -4.16 & -11.97 & 9.08 & 2.17 \\
& D & -0.37 & -6.32 & -0.90 & -4.22 & -12.01 & -3.76 & -5.34 & -4.54 & -10.90 & -28.75 & -6.70 \\
& SK & -1.89 & 16.93 & 1.39 & 1.73 & 2.44 & -2.75 & 2.33 & -6.32 & -7.87 & -14.29 & 0.15 \\
\hline EU average & & 3.48 & 26.45 & 6.28 & 5.42 & 13.43 & 6.47 & 6.06 & 1.50 & 3.34 & 8.94 & 4.95 \\
\hline \multirow{4}{*}{ Rich countries } & DK & -9.69 & 26.87 & 5.02 & -0.57 & 11.84 & -0.75 & 11.77 & -1.42 & 4.63 & 12.03 & -3.15 \\
& SWE & 8.62 & 53.99 & 9.82 & 3.50 & 14.09 & 6.78 & 10.74 & 6.84 & 14.01 & 29.35 & 10.17 \\
& IRL & 7.92 & 71.40 & 16.20 & 7.53 & 26.63 & 7.35 & 14.75 & 3.18 & 8.77 & 18.23 & 9.16 \\
\hline \multirow{2}{*}{ Poor countries } & BG & 2.68 & 23.94 & 5.54 & 8.56 & 6.06 & 4.64 & 3.02 & 19.32 & -2.40 & -2.07 & 14.05 \\
& RO & 4.63 & 12.30 & -0.09 & -3.21 & 9.50 & 0.73 & 10.50 & 17.56 & 10.48 & 12.85 & 16.99 \\
& LV & -1.81 & 9.43 & 1.25 & 12.46 & 16.52 & 17.80 & 11.06 & -9.79 & 0.76 & 24.57 & 8.60 \\
\hline Source: auth
\end{tabular}

Source: author's calculation based on EU KLEMS data

Note: $\mathrm{A}=$ Austria; $\mathrm{BG}=$ Bulgaria; $\mathrm{CZ}=$ Czech Republic; $\mathrm{D}=$ Germany; $\mathrm{DK}=$ Denmark; IRL = Ireland; LV = Latvia; $\mathrm{PL}=$ Poland; $\mathrm{RO}=$ Romania; $\mathrm{SK}=$ Slovakia; $\mathrm{SWE}=$ Sweden.

A-R are industry abbreviations; their full names are given in the methodology.

Table 7 above shows the variability of the volume of wages of high-educated workers in the wages of all workers. The first line, which represents Austria, shows that the wage volume of high-educated workers increased in all industries except $\mathrm{R}$, where it fell by almost $2 \%$ at the expense of middle- and low-educated workers. This almost describes the EU average (sixth line) trend, which implies volume growth across all industries in the order of percentage, except for B-E industries (over 26\%) and G-I (over 13\%). As regards the countries selected, this only corresponds to Sweden and Ireland. Other countries have different results and the decline in the share of high-educated workers in the wages of all workers, such as Germany, is not an exception. As for the neighboring countries of the Czech Republic, the difference in results is the most evident - this concerns both the figures themselves and their signs (growth/decline).

The correlation between the change in volume of wages for high-educated workers (of the volume of all wages) and the change in their productivity ${ }^{12}$ (essentially the correlation between the results shown in Table 7 and Table 6) is by no means as obvious as one would expect from the assumptions (see Acemoglu, 2002). Correlation coefficients for the correlation within countries are low between about -0.33 (Poland) to 0.43 (Ireland), with the exception of Romania with a relatively high coefficient of 0.74 . Looking at correlations across industries, there are similar results, ranging from $-0.31(\mathrm{~F}-$ construction) to $0.55(\mathrm{C}-$ manufacturing).

\section{Conclusions}

This paper contributes to the debate on the current changes in labor markets; specifically, it looks at changes in the structure of employment based on the education criterion in the EU

\footnotetext{
${ }^{12}$ See Table 8 and Table 9 in Appendix.
} 
countries between 2008 and 2015. The labor market can be examined from different perspectives. One option is to observe how employment structure is changing in terms of skill levels and educational attainment. Some of the existing literature puts these aspects together, making it possible to consider more educated as more skilled (Acemoglu, 1998; Krueger, 1993; Manning, 2004; Crinò, 2009).

Thematic contributions focusing on changes in structure of employment show that the demand for middle-skilled workers is declining, leading to skill-polarization (see Autor, Levy and Murnane, 2003; Goos and Manning, 2007; Goos, Manning and Salomons, 2014 and other papers which identify job polarization), while initial expectations assumed that the employee structure would evolve in favor of more educated employees, leading to skillupgrading (SBTC hypothesis) - see Acemoglu (2002), Card and DiNardo (2002) and Manning (2004).

This paper turned attention to the employment structure in all eighteen industries according to NACE. The results imply a growing proportion of more educated workers in twenty-five EU countries. Only in three countries, there was no improvement in the "education trend" over the examined period in any industry. In terms of frequency, the greatest improvement was seen in the ICT sector, but improvements are more or less spread across all industries. The worsening education trend took place marginally within two countries and two industries. In general, the potential of the labor market is growing, providing support for the SBTC hypothesis, which assumes a rise in demand for people with a higher skill level. In addition, changes in the proportion of wage volumes were examined for each country. The sorting criterion was again the level of skills which was determined by the level of education attained. Developments in EU countries correspond to the assumptions of skill-upgrading and its linkage to wages.

The results implying skill-upgrading rather than skill-polarization have raised the question of whether a higher skill level (higher level of education attainment) affected productivity, expressed as value added per worker. Here the area was narrowed from the EU28 to the Czech Republic and its surrounding countries. In addition to the EU average, the three poorest EU countries and the three richest countries were added for comparison. First, it was necessary to observe the relative changes of high-educated workers in all industries at country level. Poland and Austria recorded slightly higher proportions of high-educated workers than the Czech Republic, Germany, and Slovakia. For richer countries, there is a greater increase in the number of high-educated workers in industries $\mathrm{A}-\mathrm{I}^{13}$ (industries that are more capital-intensive) than in poor countries. In poor countries, by contrast, there is a greater increase in industries J (ICT), K (financial intermediation), and L (real estate). This may imply a catch-up effect brought about by poor countries catching up with what rich countries have already learned. Then, changes in productivity were observed and compared with the change in the number of high-educated workers. Productivity grew in most industries, but there are exceptions. In industry A (agriculture, forestry and fishing) there was a relatively large drop in productivity (by 2-26\%) despite the increase in high-educated workers in six countries. In sector J (ICT), a relatively large increase in high-educated workers across all countries was reflected in productivity gains, but not everywhere (not in three countries) and not as much across the EU as in other industries. Additionally, other results have not clearly shown a link between the change in productivity of high-educated workers and their wages (vs. Acemoglu, 2002). For example, in Germany the productivity of high-educated workers increased in all industries except Agriculture (A), but the wage volume of high-educated workers (of all employees in the economy) decreased in all industries. The ambiguous relationship within the selected countries is confirmed by

\footnotetext{
${ }^{13}$ Full names of all industries are given in the methodology.
} 
correlation coefficients, which range from about -0.3 to 0.4 (correlation at the level of individual countries), or from -0.3 to 0.4 at the level of individual sectors.

This contribution also shows how the composition of individual industries changed. For example, the results confirm that in industries Wholesale and Retail Trade, Transport and Storage, Hotels and Catering (industries considered less knowledge intensive services), the structure changed less in favor of more educated employees than in Public Administration, Health and Social Work (industries considered knowledge intensive services).

The growing proportions of more educated employees open up space for further research because this fact may not reflect the reality that people with a higher level of education perform more demanding tasks required by this higher education. Higher education is not a guarantee of the profession that requires it; these people are only more likely to have an adequate job corresponding to their skills. In practice, it is not an exception to meet people with higher education, yet they do a profession that does not require any professional education. The literature dealing with this phenomenon, called "overqualification" ${ }^{14}$, is very limited. For methodological problems with its measurement, see Erdogan et al. (2011).

\section{Acknowledgements}

This paper was supported by IGA MENDELU PEF_DP_2019023 "Labor polarization: identification, context and implication".

\section{References}

Acemoglu, D. (1998). Why do new technologies complement skills? Directed technical change and wage inequality. The Quarterly Journal of Economics, 113(4), 1055-1089. https://doi.org/10.1162/003355398555838

Acemoglu, D. (2002). Technical change, inequality, and the labor market. Journal of economic literature, 40(1), 7-72. https://doi.org/10.1257/0022051026976

Acemoglu, D., \& Autor, D. (2011). Skills, tasks and technologies: Implications for employment and earnings. In Handbook of labor economics (Vol. 4, pp. 1043-1171). Elsevier. https://doi.org/10.1016/S0169-7218(11)02410-5

Amoroso, S., \& Moncada-Paternò-Castello, P. (2018). Inward greenfield FDI and patterns of job polarization. Sustainability, 10(4), 1219. https://doi.org/10.3390/su10041219

Autor, D. (2010). The polarization of job opportunities in the US labor market: Implications for employment and earnings. Center for American Progress and The Hamilton Project, 6.

David, H., \& Dorn, D. (2013). The growth of low-skill service jobs and the polarization of the US labor market. American Economic Review, 103(5), 1553-97. https://doi.org/10.1257/aer.103.5.1553

Autor, D. H., Dorn, D., \& Hanson, G. H. (2015). Untangling trade and technology: Evidence from local labour markets. The Economic Journal, 125(584), 621-646. https://doi.org/10.1111/ecoj.12245

\footnotetext{
14 "Overqualification is a situation where an individual has surplus skills, knowledge, abilities, education, experience, and other qualifications that are not required by or utilized on the job." (Erdogan et al. 2011, p. 217) It should be noted that the above definition is very broad. In literature we find terms such as overeducation, overqualification and overskill, and the definition above includes the dimensions of skills and education. For a detailed view at the types of job/education mismatch see especially Sloane (2014), McGuinness (2006), and Davia et al. (2017).
} 
Katz, L. F. (1999). Changes in the wage structure and earnings inequality. In Handbook of labor economics (Vol. 3, pp. 1463-1555). Elsevier. https://doi.org/10.1016/S15734463(99)03007-2

Autor, D. H., Katz, L. F., \& Kearney, M. S. (2006). The polarization of the US labor market. The American economic review, 96(2), 189-194.

Autor, D. H., Levy, F., \& Murnane, R. J. (2003). The skill content of recent technological change: An empirical exploration. The Quarterly journal of economics, 118(4), 12791333. https://doi.org/10.1162/003355303322552801

Bárány, Z. L., \& Siegel, C. (2018a). Job polarization and structural change. American Economic Journal: Macroeconomics, 10(1), 57-89. https://doi.org/10.1257/mac.20150258

Bárány, Z. L., \& Siegel, C. (2018b). Biased technological change and employment reallocation (No. 1801). School of Economics Discussion Papers.

Berman, E., Bound, J., \& Machin, S. (1998). Implications of skill-biased technological change: international evidence. The quarterly journal of economics, 113(4), 1245-1279. https://doi.org/10.1162/003355398555892

Card, D., \& DiNardo, J. E. (2002). Skill-biased technological change and rising wage inequality: Some problems and puzzles. Journal of labor economics, 20(4), 733-783. https://doi.org/10.1086/342055

Crinò, R. (2009). Offshoring, multinationals and labour market: a review of the empirical literature. Journal of Economic Surveys, 23(2), 197-249. https://doi.org/10.1111/j.14676419.2008.00561.x

Davia, M. A., McGuinness, S., \& O'Connell, P. J. (2017). Determinants of regional differences in rates of overeducation in Europe. Social science research, 63, 67-80. https://doi.org/10.1016/j.ssresearch.2016.09.009

Dorn, D. (2009). Essays on inequality, spatial interaction, and the demand for skills (Doctoral dissertation, Verlag nicht ermittelbar).

Erdogan, B., Bauer, T. N., Peiró, J. M., \& Truxillo, D. M. (2011). Overqualified employees: Making the best of a potentially bad situation for individuals and organizations. Industrial and organizational psychology, 4(2), 215-232. https://doi.org/10.1111/j.17549434.2011.01330.x

Fernández-Macías, E. (2012). Job polarization in Europe? Changes in the employment structure and job quality, 1995-2007. Work and Occupations, 39(2), 157-182. https://doi.org/10.1177/0730888411427078

Goos, M., \& Manning, A. (2007). Lousy and lovely jobs: The rising polarization of work in Britain. The review of economics and statistics, 89(1), 118-133. https://doi.org/10.1162/rest.89.1.118

Goos, M., Manning, A., \& Salomons, A. (2009). Job polarization in Europe. American economic review, 99(2), 58-63. https://doi.org/10.1257/aer.99.2.58

Goos, M., Manning, A., \& Salomons, A. (2014). Explaining job polarization: Routine-biased technological change and offshoring. American economic review, 104(8), 2509-26. https://doi.org/10.1257/aer.104.8.2509

ISCED. 1997. International Standard Classification of Education. UNESCO UIS. [cit. 201812-14]. Cited from http://uis.unesco.org/en/topic/international-standard-classificationeducation-isced 
Jäger, K. (2017, July). EU KLEMS Growth and Productivity Accounts 2017 Release, Statistical Module1. In The Conference Board.

Krueger, A. B. (1993). How computers have changed the wage structure: evidence from microdata, 1984-1989. The Quarterly Journal of Economics, 108(1), 33-60. https://doi.org/10.2307/2118494

Manning, A. (2004). We can work it out: the impact of technological change on the demand for low-skill workers. Scottish Journal of Political Economy, 51(5), 581-608. https://doi.org/10.1111/j.0036-9292.2004.00322.x

Mason, G., Williams, G., \& Cranmer, S. (2009). Employability skills initiatives in higher education: what effects do they have on graduate labour market outcomes?. Education Economics, 17(1), 1-30. https://doi.org/10.1080/09645290802028315

Mazzolari, F., \& Ragusa, G. (2013). Spillovers from high-skill consumption to low-skill labor markets. Review of Economics and Statistics, 95(1), 74-86. https://doi.org/10.1162/REST_a_00234

McGuinness, S. (2006). Overeducation in the labour market. Journal of economic surveys, 20(3), 387-418. https://doi.org/10.1111/j.0950-0804.2006.00284.x

Michaels, G., Natraj, A., \& Van Reenen, J. (2014). Has ICT polarized skill demand? Evidence from eleven countries over twenty-five years. Review of Economics and Statistics, 96(1), 60-77. https://doi.org/10.1162/REST_a_00366

Ngai, L. R., \& Petrongolo, B. (2017). Gender gaps and the rise of the service economy. American Economic Journal: Macroeconomics, 9(4), 1-44. https://doi.org/10.1257/mac.20150253

Oldenski, L. (2014). Offshoring and the polarization of the US labor market. ILR Review, 67(3_suppl), 734-761. https://doi.org/10.1177/00197939140670S311

O'Mahony, M., \& Timmer, M. P. (2009). Output, input and productivity measures at the industry level: the EU KLEMS database. The economic journal, 119(538), F374-F403. https://doi.org/10.1111/j.1468-0297.2009.02280.x

Pertold-Gebicka, B. (2014). Job Market Polarization and Employment Protection in Europe. Economic Studies \& Analyses/Acta VSFS, 8(2).

Sloane, P. J. (2014). Overeducation, skill mismatches, and labor market outcomes for college graduates. IZA World of Labor. https://doi.org/10.15185/izawol.88

Weiss, M. (2008). Skill-biased technological change: Is there hope for the unskilled?. Economics Letters, 100(3), 439-441. https://doi.org/10.1016/j.econlet.2008.03.022. 


\section{Appendix}

Correlation between the change in volume of wages for high-educated workers (on the volume of all wages) and the change in their productivity (value added per worker)

Table 8.

Correlation across countries

\begin{tabular}{lc}
\hline A & 0.207 \\
CZ & -0.024 \\
D & -0.234 \\
PL & -0.332 \\
SK & 0.138 \\
\hline EU average & -0.279 \\
\hline DK & -0.271 \\
SWE & -0.241 \\
IRL & 0.429 \\
\hline BG & 0.050 \\
RO & 0.739 \\
LV & -0.207 \\
\hline
\end{tabular}

Source: author's calculation based on EU KLEMS data

Note: $\mathrm{A}=$ Austria; $\mathrm{BG}=$ Bulgaria; $\mathrm{CZ}=$ Czech Republic; $\mathrm{D}=$ Germany; $\mathrm{DK}=$ Denmark; IRL = Ireland; LV = Latvia; $\mathrm{PL}=$ Poland; $\mathrm{RO}=$ Romania; $\mathrm{SK}=$ Slovakia; $\mathrm{SWE}=$ Sweden.

Table 9.

Correlation across sectors

\begin{tabular}{lllllllllll}
\hline A & B-E & C & F & G-I & J & K & L & M-N & O-Q & R \\
\hline-0.277 & 0.386 & 0.554 & -0.312 & 0.027 & 0.026 & 0.123 & 0.398 & 0.416 & -0.209 & 0.441 \\
\hline
\end{tabular}

Source: author's calculation based on EU KLEMS data

A-R are industry abbreviations; their full names are given in the methodology. 